\title{
Microbial analysis of raw cows' milk used for cheese-making: influence of storage treatments on microbial composition and other technological traits
}

\author{
Elena Franciosi • Luca Settanni • Nicola Cologna • \\ Agostino Cavazza $\cdot$ Elisa Poznanski
}

Received: 20 March 2010/ Accepted: 5 May 2010/Published online: 16 May 2010

(C) Springer Science+Business Media B.V. 2010

\begin{abstract}
Raw milk used to produce Grana cheese was subjected to several treatment regimes, including varying temperatures and storage times. Milk from morning and evening milking were transferred to a dairy factory separately (double delivery) or together (single delivery), after storage at the farm for $12 \mathrm{~h}$; in the former case, milk was stored at 12 or $8^{\circ} \mathrm{C}$, whereas, in the latter, it was kept at ambient temperature or $18^{\circ} \mathrm{C}$. Values of $\mathrm{pH}$ of the vat milk were lower for milk samples kept at room temperature, while other physico-chemical parameters and rheological characteristics tested did not show significant differences linked to the different storage temperatures of milk used for "Grana Trentino" cheese production. Total microorganisms and several microbial groups (psychrotrophic bacteria, coliforms, mesophilic and termophilic lactic acid bacteria, including enterococci, pseudomonads
\end{abstract}

E. Franciosi $(\bowtie) \cdot$ A. Cavazza $\cdot$ E. Poznanski

IASMA Research and Innovation Centre, Fondazione Edmund Mach, Food Quality and Nutrition Area, Innovative Food Technologies, Via E. Mach 1, 38010 San Michele all'Adige (TN), Italy

e-mail: elena.franciosi@iasma.it

L. Settanni $(\bowtie)$

SENFIMIZO Department, Section of Phytopathology and Agricultural Microbiology, University of Palermo, Viale delle Scienze 4, 90128 Palermo, Italy

e-mail: luca.settanni@unipa.it

N. Cologna

Dipartimento di Scienze Animali, Facoltà di Agraria, Università di Padova, Viale dell'Università 16, 35020 Legnaro (PD), Italy

Present Address:

E. Poznanski

Faculty of Science and Technology, Free University of Bolzano-

Bozen, Piazza Università 1, 39100 Bolzano, Italy and clostridia) were detected and quantified by classical (plate count and most probable number) techniques, after each technological treatment for a total of 212 milk and cream samples. The application of a culture-independent microbiological strategy, consisting of denaturing gradient gel electrophoresis, allowed the recognition of several bacterial genera and species.

Keywords Denaturing gradient gel electrophoresis . Grana cheese - Milk microflora - Raw cows' milk . Refrigeration

\section{Introduction}

Milk is a rich medium for the development of a wide variety of microorganisms. The quality of milk strongly depends on the microorganisms living in it, whose ability to grow is also influenced by technological parameters such as cooling and holding temperature, as well as storage time (Heeschen 1996; Slaghuis 1996; Murphy and Boor 2000). Refrigeration at the farms constitutes the main strategy applied to preserve raw milk and the resulting dairy products from spoilage. This operation has, however, the drawback of favouring the growth of Gram-negative proteolytic psychrotrophic bacteria which might cause spoilage of milk and milk products, due to their ability to produce thermostable proteases that hydrolyze casein and decrease the yield and sensory quality of dairy products (Dogan and Boor 2003; Sørhaug and Stepaniak 1997). Thus, the storage temperature of raw milk after milking should be low to inhibit the growth of pathogenic and spoilage mesophilic bacteria, without allowing the development of psychrotrophic bacteria. Furthermore, the presence of some mesophilic bacteria in raw milk, e.g. non starter lactic acid bacteria (NSLAB), can be 
desirable, since they may play a positive role in artisanal and traditional cheeses (Foulquié Moreno et al. 2006).

Parmesan and Grana cheeses are hard-cooked cheeses that undergo a ripening period of up to 2 years and are economically relevant in northern Italy. "Grana trentino" cheese is produced in the Alpine province of Trento; it is produced by the "Grana Padano" consortium and enjoys a protected designation of origin (D.P.R. $\mathrm{n}^{\circ} 1269$ Gazzetta Ufficiale 1955). The first fermentation of this cheese is triggered, as with Parmesan, by adding a natural starter culture obtained from the spontaneous fermentation of part of the previous day's whey (Neviani and Carini 1994) to partially skimmed raw cows' milk.

The technology of production of Grana cheese includes a partial milk skimming that is performed by cream surfacing, a process in which, during milk resting, the fat globules cluster together and float, leading to the separation of cream from skimmed milk (Kohnhorst 2001). Bacteria can accumulate at the surface of raw milk because they often associate with the rising fat globules (Belknap et al. 1978). Thus, skimming has a major effect on the microbiota of the resulting milk, greatly improving its quality (Corradini 1995).

So far, a few studies have reported the effects of storage temperature on creaming, microbial evolution and physicochemical, as well as coagulation properties of milk. Malacarne et al. (2008) focused on the physico-chemical and rheological parameters and studied the microflora evolution during creaming carried out at temperatures $\geq 18^{\circ} \mathrm{C}$, without considering different storage times of milk at the farm. Furthermore, milk microflora was investigated by a culture-dependent approach.

This work is part of a project aimed to improve the quality of "Grana Trentino" cheese production. In particular, the objectives of the present study were (1) to evaluate the physico-chemical, rheological and microbiological characteristics of raw cows' milk maintained at different temperatures and storage times at the farms before its delivery to the dairy factory, (2) to estimate differences in bacterial concentrations during milk maturation and skimming, and (3) to detect the eubacterial species resident in whole, skimmed milk and cream samples, including the non cultivable bacteria, by denaturing gradient gel electrophoresis (DGGE).

\section{Materials and methods}

\section{Milk supply}

Raw cows' milk (Table 1) to be processed into "Grana Trentino" cheese was collected from two farms located in the Trentino region (northern Italy) and delivered to the local dairy factory (Caseificio comprensoriale di Primiero,
Mezzano, TN, Italy). Bulked milks were subjected to four thermal regimes after milking: storage at ambient temperature, or cooling to 18,12 or $8^{\circ} \mathrm{C}$. In trials with no refrigeration or $18^{\circ} \mathrm{C}$ cooling, the morning and evening milkings were delivered separately (double milk delivery) to the dairy factory in $50-\mathrm{L}$ cans (trial without refrigeration) or by a temperature-controlled road tanker (trial with cooling at $18^{\circ} \mathrm{C}$ ). In the 12 and $8^{\circ} \mathrm{C}$ trials the milk from the morning milking was kept refrigerated under slow stirring for $12 \mathrm{~h}$ then mixed with the evening milk and transferred once a day, at evening, to the dairy factory (single milk delivery) in a temperature-controlled road tanker. When evening and morning milk were delivered separately, overnight skimmed evening milk was mixed with the whole morning milk at the dairy factory. Each day of cheese production with double daily milk delivery, five samples were collected and analysed: evening whole milk (EWM), skimmed milk (SM), cream (Cr), morning whole milk (MWM) and vat milk (VM; Table 1 ). In case of single daily milk delivery, three samples were analyzed: whole milk (WM), VM and Cr.

The samples were collected in spring (April-May) and summer (August-September) 2007 during a production period of 16 weeks (four per month). Each experiment was repeated for four consecutive days per week, 1 week per month, for a total of 16 sampling days.

\section{Skimming process}

Two different creaming technologies are used if milk is delivered to the cheese factory once or twice a day. In double milk delivery experimentations, creaming occurred by overnight rest at $15^{\circ} \mathrm{C}$. Evening milk (ca. $600 \mathrm{~kg}$ ) was placed into a 700 l-shallow tank in the dairy factory. The day after, skimmed milk (ca. $550 \mathrm{~kg}$ ) is added to the whole milk (ca. $500 \mathrm{~kg}$ ) collected in the morning and put in a copper vat for cheese making. Milk delivered once a day (ca. $1180 \mathrm{~kg}$ from experiments at 12 or $8^{\circ} \mathrm{C}$ ) was placed into a 1,200 l-shallow tank and the creaming was carried out without temperature control. After creaming, skimmed milk was transferred to the copper vat.

Measurements and chemical analysis of milk and cream samples

Temperatures were recorded with a 175-T2 data logger (Testo, Settimo Milanese, Italy). Values of $\mathrm{pH}$ in milk samples were measured with a portable $\mathrm{pH}$ meter (Knick Portamess 910, Berlin, Germany) connected to a Cheesetrode (Hamilton Co., Reno, NV, USA) electrode.

Fat and casein contents in milk samples were evaluated by infrared analysis (Biggs 1978) with a Milko-Scan 134 A/B (Foss Electric, DK-3400 Hillerod, Denmark). Acidity of samples was determined by titrating $100 \mathrm{ml}$ aliquots 


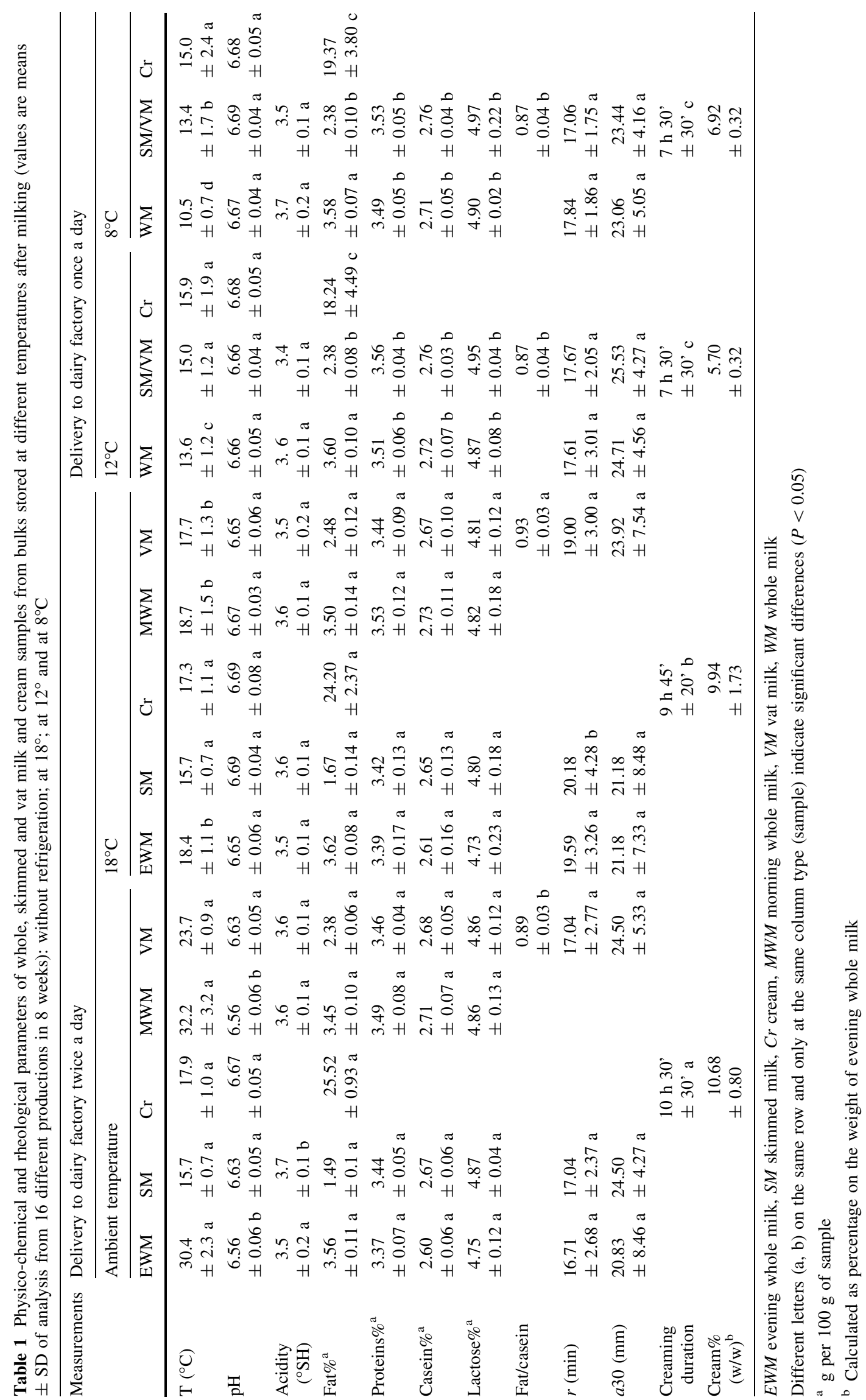


with $0.25 \mathrm{~N} \mathrm{NaOH}$, using phenolphthalein as indicator (end-point $\mathrm{pH}$ 8.30) and the results were expressed in ${ }^{\circ} \mathrm{SH}$.

Lactodynamographic analysis

Milk rheological parameters was analysed, without $\mathrm{pH}$ standardization, by Formagraph (Italian Foss Electric, Padova, Italy), obtaining the following parameters: $r=$ clotting time (min), time from the addition of rennet to the beginning of coagulation; $a_{30}=$ curd firmness (mm), measured $30 \mathrm{~min}$ after the addition of rennet (Zannoni and Annibaldi 1981).

\section{Microbiological analysis}

Decimal dilutions of whole milk, skimmed milk, milk mixture and cream samples were prepared in peptone water (0.1\% mycological peptone, Oxoid, Basingstoke, UK); cream samples were previously homogenized in a Laboratory Blender Stomacher 400 (Seward, London, UK) for 2 min at the highest speed to disrupt fat globules. Dilutions were plated and incubated as follows: total bacterial count (TBC) on PCA added with $1 \mathrm{~g} / 1$ skimmed milk (SkM), incubated aerobically at $30^{\circ} \mathrm{C}$ for $24 \mathrm{~h}$; psychrotrophic bacteria on PCA-SkM, incubated aerobically for 7 days at $7^{\circ} \mathrm{C}$; coliforms on violet red bile agar (VRBA), incubated anaerobically for $24 \mathrm{~h}$ at $37^{\circ} \mathrm{C}$; mesophilic rods and cocci LAB on MRS and M17 agar, incubated at $30^{\circ} \mathrm{C}$ anaerobically for $48 \mathrm{~h}$ and aerobically for $24 \mathrm{~h}$, respectively; thermophilic LAB on whey agar medium (WAM) prepared as reported by Gatti, Lazzi, Rossetti, Mucchetti, and Neviani (2003), incubated anaerobically for 4 days at $45^{\circ} \mathrm{C}$; enterococci on kanamycin aesculin azide (KAA) agar, incubated aerobically for $24 \mathrm{~h}$ at $37^{\circ} \mathrm{C}$; pseudomonads on Pseudomonas agar base (PAB) supplemented with $10 \mathrm{mg} /$ $\mathrm{ml}$ cetrimide fucidin (Oxoid), incubated aerobically for $48 \mathrm{~h}$ at $20^{\circ} \mathrm{C}$. Clostridia content was estimated by the most probable number (MPN) technique using a $3 \times 3$ scheme: undiluted samples and decimal dilutions were pasteurized at $85^{\circ} \mathrm{C}$ for $15 \mathrm{~min}$ and inoculated into reinforced clostridial medium (RCM) supplemented with $1.4 \%$ (v/v) Na-lactate (Merck, Darmstadt, Germany); after that, test tubes were sealed with paraffin:vaseline (1:6) and incubated for 7 days at $37^{\circ} \mathrm{C}$. All media were purchased from Oxoid.

Total DNA extraction and DGGE analysis

DNA was extracted from milk and cream samples according to Meiri-Bendek et al. (2002); DNA extracts were then used as templates for PCR reactions.

DGGE samples were prepared by performing PCR amplification of the $\mathrm{V} 3$ region of $16 \mathrm{~S}$ rRNA gene according to Ercolini et al. (2001). DGGE was carried out using the DCcode Universal mutation Detection system (Bio-Rad,
Hercules, CA, USA) on $16 \mathrm{~cm} \times 16 \mathrm{~cm} \times 1 \mathrm{~mm}$ gels. PCR products $(8 \mu \mathrm{l})$ were loaded onto gels with $8 \%(\mathrm{w} / \mathrm{v})$ acrylamide (acrylamide-bisacrylamide 37.5:1) and a 25-60\% urea/formamide gradient, increasing in the direction of electrophoresis. A $100 \%$ denaturing solution consisted of $7 \mathrm{M}$ urea and $40 \%$ (v/v) deionized formamide. Electrophoresis was conducted in $1 \times$ TAE $[40 \mathrm{mM}$ Tris, $20 \mathrm{mM}$ acetic acid and 1 M EDTA (pH 8.0)] buffer at $150 \mathrm{~V}$ for $5 \mathrm{~h}$ at $60^{\circ} \mathrm{C}$. After runs, gels were stained for $15 \mathrm{~min}$ in an ethidium bromide solution, rinsed in distilled $\mathrm{H}_{2} \mathrm{O}$ for $20 \mathrm{~min}$ and photographed on a UV transilluminator.

DGGE fragment sequencing and bacterial identification

DGGE fragments found at different positions along the polyacrylamide gel were excised and eluted overnight in $100 \mu \mathrm{l}$ sterile MilliQ $\mathrm{H}_{2} \mathrm{O}$ at $4^{\circ} \mathrm{C}$. One microliter of the eluted DNA of each DGGE fragment was re-amplified as above with primers that did not contain the GC-clamp. PCR products were purified using the Exo-SAP-IT kit (USB Co., Cleveland, $\mathrm{OH}$ ) and sequenced through the BigDye Terminator v1.1 cycle sequencing kit (Applied Biosystems, Foster City, CA), following manufacturer's instruction, on an ABI PRISM 3100 sequencer (Applied Biosystems). Sequence identities were verified by a BLASTN (Altschul et al. 1997) search against the NCBI non-redundant sequence database located at http://www.ncbi.nlm.nih.gov.

Statistical analysis

Analysis of variance (ANOVA, StatSoft, Inc. 2008; STATISTICA data analysis software system, version 8.0. www.statsoft.com; significance level $P<0.05$ ) was used to evaluate the influence of independent variables such as milk storage temperature $\left(12\right.$ and $8^{\circ} \mathrm{C}$ in the single milk delivery and $18^{\circ} \mathrm{C}$ or not refrigerated in the double milk delivery) and season of production on the chemical and microbiological parameters measured on milk.

A normalization step was applied to each variable to avoid possible distortions arising from the different magnitudes of the numerical values associated with the different variables. This normalization involved that all microbiological data were expressed as their decimal logarithm to obtain the homogeneity of variance.

\section{Results and Discussion}

Chemical and technological properties of milk and cream samples

Milk for "Grana Trentino" cheese production was kept at different temperatures during storage before processing. 
Table 1 reports the means and standard deviations of the physico-chemical and rheological characteristics of milk samples for the different experimentations. In case of no refrigeration, EWM reached the cheese factory at 30.4 and $32.2^{\circ} \mathrm{C}$ at evening and morning, respectively. $\mathrm{SM}$ and $\mathrm{Cr}$ had lower temperatures after overnight separation in temperature-controlled tanks (15.7 and $17.9^{\circ} \mathrm{C}$, respectively), and final vat milk temperature was $23.7^{\circ} \mathrm{C}$. Similar temperatures were observed for $\mathrm{SM}$ and $\mathrm{Cr}$ samples derived from EWM kept at $18.0^{\circ} \mathrm{C}$. When refrigerated at 12 or $8^{\circ} \mathrm{C}$, the milk temperature was slightly lower, in fact SM temperature in the vat was 15.0 and $13.4^{\circ} \mathrm{C}$, respectively. In these latter two cases, the creaming step was not temperature controlled. Values of milk $\mathrm{pH}$ were always slightly lower in milk and cream samples of unrefrigerated trials and the difference was significant in evening and morning whole milk. Probably the storage without refrigeration before delivery did not slow down the activity of mesophilic LAB, leading to lowered milk $\mathrm{pH}$ values. In SM from unrefrigerated milk, the acidity was significant higher than in the others trials, probably due to weak acid production by microorganisms that developed during early stages of creaming, when the temperature was still favourable (the temperature decreased from 30.4 to $15.7^{\circ} \mathrm{C}$ in about $2 \mathrm{~h}$ ). In all other cases, the acidity ranged between 3.5 and $3.7^{\circ} \mathrm{SH}$ without significant differences $(P<0.05)$ between trials. Though not significant by ANOVA, the acidity was always lower in unrefrigerated SM than in the cooled milks, and the $\mathrm{pH}$ decreased significantly for the trial carried out at ambient temperature. This could be correlated with the significantly higher bacterial counts in $\mathrm{SM}$ and $\mathrm{Cr}$ from milk kept at ambient temperature than refrigerated milk samples (Table 2). Higher concentrations of bacteria and lower $\mathrm{pH}$ suggest that, after creaming without refrigeration system, bacterial development occurs during overnight skimming.

Fat, protein and casein values and fat/casein $(\mathrm{F} / \mathrm{C})$ ratio of milk are reported in Table 1. In the EWM the fat amount did not greatly differ among the experiments (from 3.56 to $3.62 \%)$. Fat values observed in vat milk were always in agreement with those found in Parmigiano Reggiano cheese production, reported to be in a range between 2.02 and $3.13 \%$, while protein and casein contents were higher than those reported by Formaggioni et al. (2005). Hence, in our vat milk samples, the ratio $\mathrm{F} / \mathrm{C}$ was lower. Because of the shorter creaming process, when milk was collected and refrigerated at 12 or $8^{\circ} \mathrm{C}, \mathrm{SM}$ samples showed a significantly higher fat content than unrefrigerated milk or milk stored at $18^{\circ} \mathrm{C}$. Vat milk from refrigeration at $18^{\circ} \mathrm{C}$ had higher fat amount $(2.48 \%)$ and lower casein amounts $(2.67 \%)$ than other trials, and a F/C significantly higher (0.93) than other experiments. Milk casein content affects the characteristics of curd and cheese yield. In milk containing higher amounts of casein, curd formation occurs in a shorter time and it is firmer and more contractible, thus facilitating a more uniform draining of whey (Fossa et al. 1994).

Generally bulk milk clotting characteristics ( $r$ and $a_{30}$ ) did not greatly differ between trials. However, in milk refrigerated at $18^{\circ} \mathrm{C}$, the $r$ value was 19.59 in EWM, 20.18 in SM and 19.00 in vat milk. These values were significantly higher than the mean values of the other trials, e.g. 16.71, 17.61 and 17.84 of EWM of unrefrigerated and 12 or $8^{\circ} \mathrm{C}$ refrigerated milk, respectively. However, in all trials, $a_{30}$ was higher in SM and VM than in the respective EWM confirming the observation of Sandri et al. (2007) that the creaming step is not only useful to calibrate the fat amount in the vat milk, but also to improve its aptitude to coagulate. Casein amounts and milk clotting parameters were different from those of "Parmigiano Reggiano" cheese vat milk (Formaggioni et al. 2005). This observation maybe due to the fact that milk used for "Grana Trentino" cheese-making mainly derives from Brown herds, which shows higher casein values and better aptitudes to coagulations than milk produced by the Fresian cows commonly used for "Parmigiano Reggiano" production (Mariani et al. 1984; Pecorari et al. 1987).

Creaming times for milk refrigerated at 12 or $8^{\circ} \mathrm{C}$ were shorter than those of unrefrigerated milk or in milk refrigerated at $18^{\circ} \mathrm{C}$, thus determining different percentages of cream in VM after separation.

Our physico-chemical and rheological results showed that, in spite of microbiological and chemical differences of SM in different trials, vat milk samples collected from bulk used to produce "Grana Trentino" cheese did not show significant physical differences linked to the storage temperatures. Independent of storage temperature, all the vat milk samples analysed presented good cheese-making aptitudes.

Microbial counts in milk and cream samples

Microbial populations present in milk and cream batches from different temperature storages are shown in Table 2. Total counts in EWM ranged between 3.5 and $4.0 \mathrm{log}$ c.f.u./ml. Total microbial counts after the creaming process decreased, but not significantly $(P<0.05)$ : in SM samples, counts were only $0.3-0.7 \log$ c.f.u./ml lower than those from the corresponding EWM. Higher differences were observed in SM from unrefrigerated milk than in SM from all others trials. Total bacteria content in vat milk was similar to that in the EWM and no statistically significant differences were found among the four experiments. In all trials, the TBC in milk samples was probably composed mainly by mesophilic cocci, whose content was almost in 


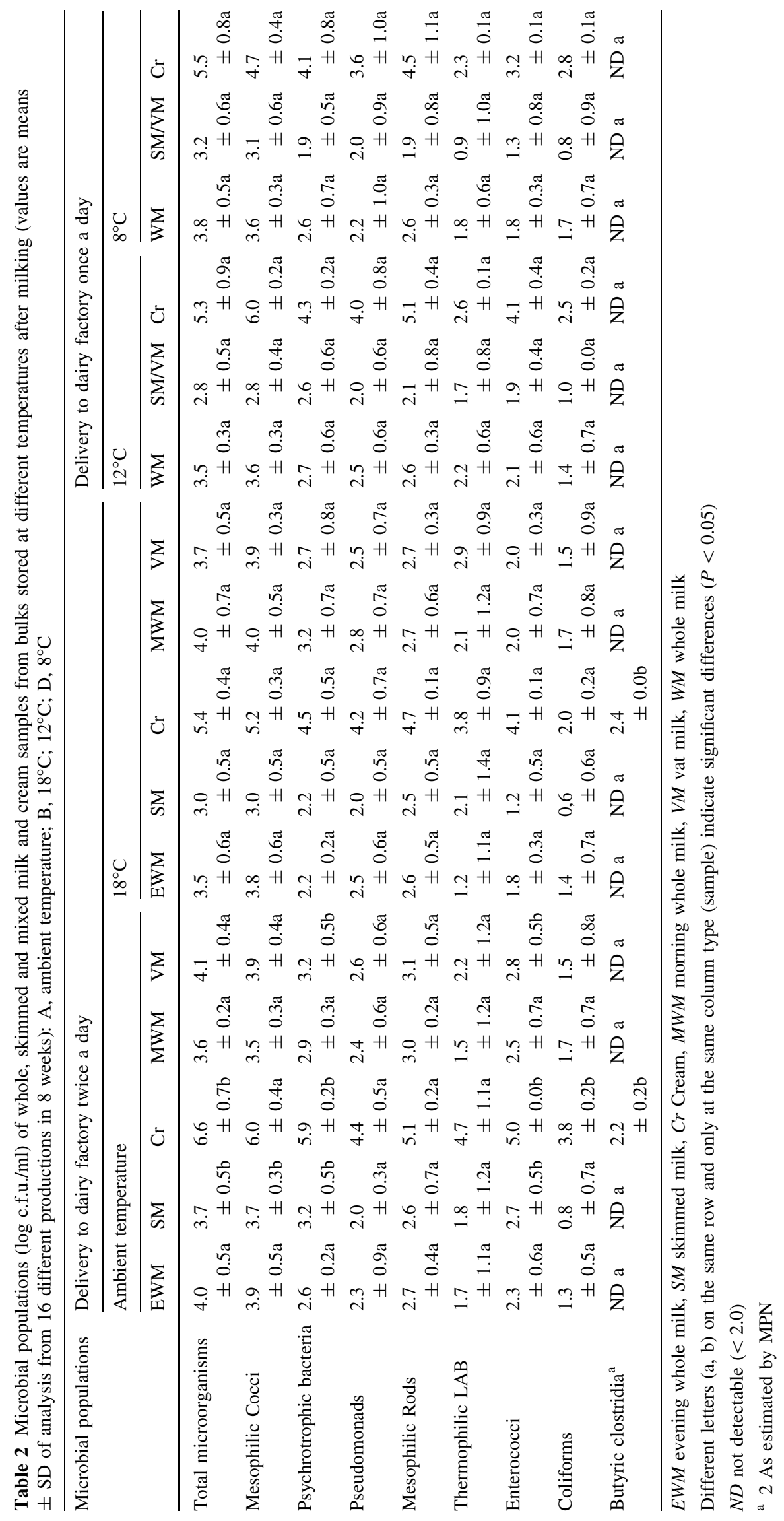


the same range $( \pm 0.3 \log$ c.f.u. $/ \mathrm{ml})$ of the respective TBC value. On the other hand, cream samples showed higher differences between TBC and mesophilic cocci content: mesophilic cocci counts differed by about $0.8 \log$ c.f.u. $/ \mathrm{ml}$ from the respective TBC value. Different TBC concentrations were found in cream samples ranging from 5.3 to 6.6 $\log$ c.f.u./ml; the highest cell counts were found in creams originating from unrefrigerated milk. These results clearly show the effect of creaming on the debacterization: cell concentrations in cream samples were always at least two orders of magnitude higher than those of SM, reaching the greatest difference of almost three orders in cream from unrefrigerated milk. This observation highlights that milk refrigeration limits the proliferation of microorganisms during night resting of milk.

No differences in psychrotrophic bacterial counts were found among EWM samples. After creaming, the psychrotrophic bacteria counts in refrigerated SM samples were as low as in the EWM before creaming. Only in SM from unrefrigerated milk these bacteria grew to $3.2 \mathrm{log}$ c.f.u./ml. During creaming, the growth of psychrotrophic bacteria in unrefrigerated milk reached the concentration of $5.9 \log$ c.f.u. $/ \mathrm{ml}$ in $\mathrm{Cr}$ samples, while in the other trials $\mathrm{Cr}$ counts were one $\log$ lower $(4.5,4.3,4.1 \log$ c.f.u. $/ \mathrm{ml}$, in $\mathrm{Cr}$ samples from 18,12 and $8^{\circ} \mathrm{C}$ refrigeration, respectively). Pseudomonads, mesophilic rods and thermophilic LAB represented a minor part of total bacterial community in milk (count values in the range 1.0-3.0 $\log$ c.f.u. $/ \mathrm{ml}$ ) and were found in higher amounts in creams, without significant differences among the four trials. Enterococci were present in all EWM samples (1.8-2.3 log c.f.u./ml). These values assessed the good microbiological quality of the milk delivered to the cheese factory, independent of storage temperature.

After creaming, enterococci counts were higher in SM, $\mathrm{Cr}$, and VM samples obtained from unrefrigerated milk. These observations suggested that keeping the milk without refrigeration before delivery to cheese factory allows the growth of this group of bacteria during overnight creaming.

Coliforms were found in the same concentration range (1.3-1.7 $\log$ c.f.u. $/ \mathrm{ml})$ in all whole milk samples. After creaming, a reduction of 0.4-0.9 $\log$ c.f.u./ml was observed in all SM samples. Coliform counts in $\mathrm{Cr}$ samples were higher than milk samples. Furthermore, $\mathrm{Cr}$ samples from unrefrigerated milk showed coliform levels significantly higher $(P>0.05)$ than all other $\mathrm{Cr}$ samples. Butyric clostridia were found only in cream samples deriving from milk stored without refrigeration or at $18^{\circ} \mathrm{C}$.

In Grana cheese-making, the process of milk-creaming has two effects: (1) skimming of milk; and (2) the removal of bacteria from milk. Our results clearly showed that the total number of microorganisms did not greatly vary between EWM and SM samples. This observation is probably due to two opposite phenomena: microbial growth does take place in milk during overnight standing, but creaming contemporarily removes bacteria together with fat globules. Undoubtedly, the higher bacterial cell count found in cream samples was due to the overnight growth of milk microflora, but it also depended on the concentration of proliferating microorganisms in the upper fat layer (cream). In fact, after spontaneous milk creaming, the microbial concentration in SM samples was limited. Besides the physical action of creaming on removing bacteria from the EWM, the storage temperature at which milk was kept before delivery to the cheese factory played an important role in maintaining microbial growth at low levels. Storage without refrigeration allowed the growth of psychrotrophic bacteria, which are potentially dangerous for the coagulation aptitude of vat milk and can negatively affect cheese ripening.

\section{Bacterial identification}

The presence of different bacterial species in milk and cream samples was revealed by DGGE patterns of the amplified V3 region of $16 \mathrm{~S}$ rDNA as shown in Fig. 1. The identification process was based on DGGE fragment sequencing, followed by BLAST comparison in GenBank (http://www.ncbi.nlm.nih.gov; sequence similarities are reported in Table 3). Some DNA fragments could not be associated to any bacterial species because of sequencing failure.

All milk and cream samples showed enterococcal fragments, even if in certain samples, they were weak. Escherichia coli and Streptococcus thermophilus were found in all milk samples. S. thermophilus fragments were not found in milks stored at ambient temperature: in these samples other thermophilic species (Enterococcus spp.) were found. All whole milk samples were similar in species composition: they showed DGGE fragments sequenced as thermophilic, mesophilic and psycrotrophic species, as well as coliforms. Even if EWM samples were similar in species composition, VM samples from different storage temperatures showed some differences. In general, in refrigerated vat milk samples at 8 and $12^{\circ} \mathrm{C}$, a lower number of DNA fragments was found. Pseudomonads were found in $12^{\circ} \mathrm{C}$ VM samples and Acinetobacter spp. were mostly detected in unrefrigerated VM samples.

By means of a culture-independent approach, thermolabile (Acinetobacter spp., Pseudomonas spp. and E. coli) and thermoduric (Enterococcus spp.) bacteria were detected in both milk and cream samples, while no aerobic spore forming bacteria were found. Furthermore, staphylococci were found in all $\mathrm{Cr}$ and also in EWM and MWM samples, with Staphylococcus saprophyticus clearly recognized. 


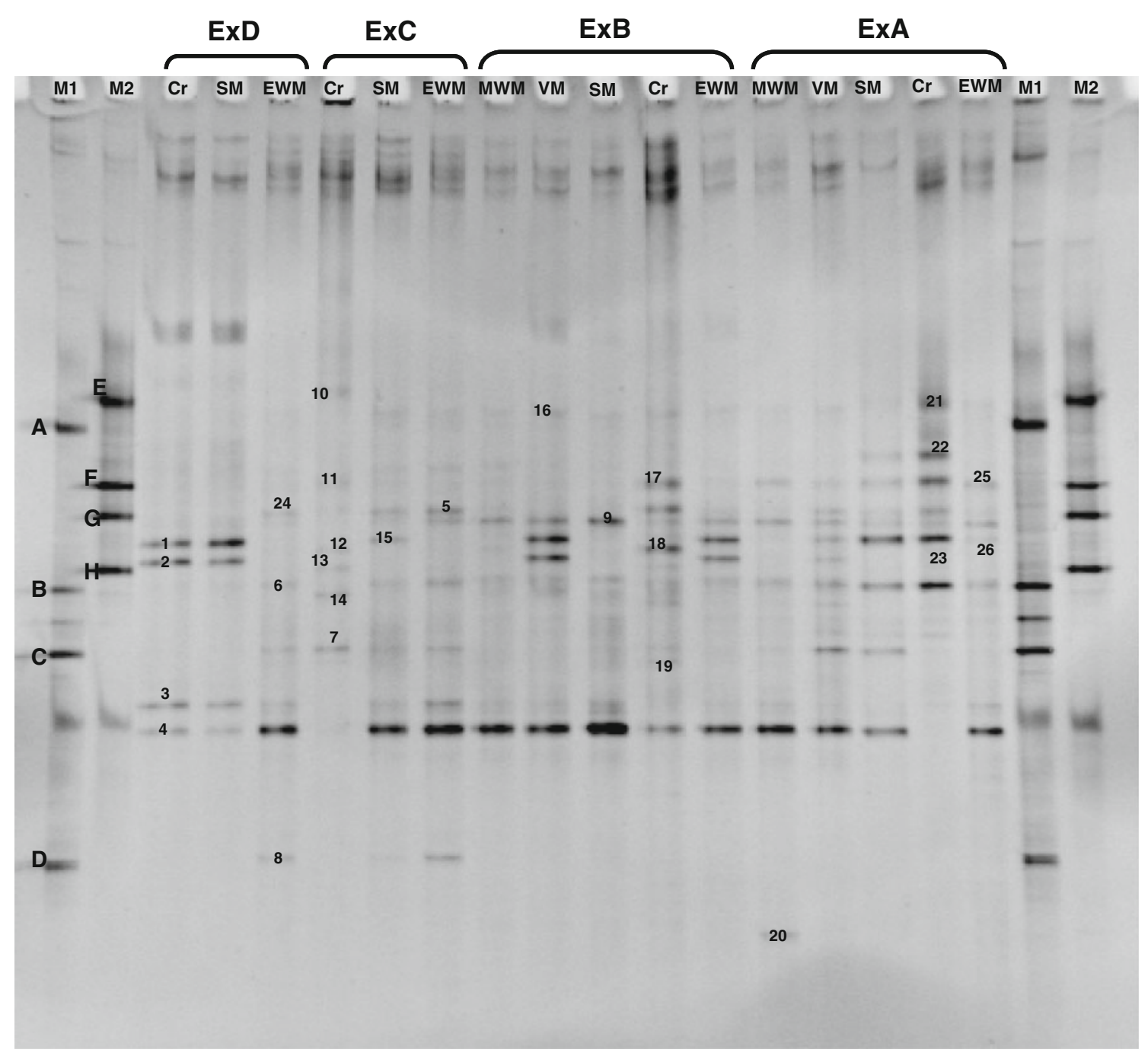

Fig. 1 DGGE profiles of 16S rRNA gene V3 regions obtained from different evening whole milk $(E W M)$, cream $(C r)$, skim milk $(S M)$, morning whole milk (MWM) and vat milk $(V M)$ samples from different experimentations: a ambient temperature; b $18^{\circ} \mathrm{C}$; c $12^{\circ} \mathrm{C}$; d $8^{\circ} \mathrm{C}$. Lanes: $M 1$ marker 1 including Lactobacillus plantarum DSMZ $20174^{\mathrm{T}}$ (a), Streptococcus gallolyticus subsp. macedonicus $15789^{\mathrm{T}}$

Staphylococci are part of the ubiquitous aerobic mesophilic microorganisms of raw milk (Özer 2000). These results are in line with those reported for milk that did not undergo a heat treatment (Franciosi et al. 2009a; Franciosi et al. 2009b).

Gram-positive rods, generally associated with raw milk (Özer 2000), were mainly represented by LAB. The rod shaped LAB found in samples analyzed included all species of dairy interest: L. helveticus, L. delbrueckii subsp. bulgaricus and L. rhamnosus/L. casei. Cocci LAB with technological aptitudes were also identified, in particular, S. thermophilus and Ln. mesenteroides, both species generally employed as starter culture (Fox et al. 2004; Franciosi et al. 2008). (b), Lactococcus lactis DSMZ $20069^{\mathrm{T}}$ (c), Lactobacillus casei DSMZ $20011^{\mathrm{T}}$ (d); M2 marker 2 including Lactococcus garviae DSMZ $20684^{\mathrm{T}}$ (e), Leuconostoc mesenteroides DSMZ $20346^{\mathrm{T}}$ (f), Enterococcus faecium DSMZ $20477^{\mathrm{T}}$ (g), Pediococcus pentosaceus DSMZ $20336^{\mathrm{T}}(\mathbf{h})$. DGGE fragments have been enumerated from 1 to 26 and the corresponding identities are reported in Table 3

The combination of data from classical culture-dependent plate counts and DGGE gave a clear picture of the microbial composition of the samples analyzed. Plate counts allowed the quantification of microorganisms at group level, while DGGE revealed the presence of several bacterial genera and species. These data were complementary, since the culture-independent method recognized bacteria that generally grow in the media used for plate counts. However, although a different intensity of the DNA fragments may be indicative of the cell concentration, the DGGE technique cannot provide the precise order of magnitude of each bacterium identified.

A discordance between culture-dependent and cultureindependent methods was noticed between MPN technique 
Table 3 DGGE fragment sequence similarities

\begin{tabular}{|c|c|c|}
\hline Fragments & Closest relative & $\begin{array}{l}\text { Similarity } \\
(\%)\end{array}$ \\
\hline 1 & Lactobacillus helveticus & 100 \\
\hline 2 & $\begin{array}{l}\text { Lactobacillus delbrueckii subsp. } \\
\text { bulgaricus }\end{array}$ & 99 \\
\hline 3 & Streptococcus thermophilus & 100 \\
\hline 4 & Escherichia coli & 97 \\
\hline 5 & Enterococcus spp. & $<97$ \\
\hline 6 & Acinetobacter spp. & $<97$ \\
\hline 7 & Acinetobacter spp. & $<97$ \\
\hline 8 & $\begin{array}{l}\text { Lactobacillus rhamnosus/ } \\
\text { Lactobacillus casei }\end{array}$ & 99 \\
\hline 9 & SF & \\
\hline 10 & Acinetobacter spp. & $<97$ \\
\hline 11 & Pseudomonas spp. & $<97$ \\
\hline 12 & Staphylococcus saprophyticus & 97 \\
\hline 13 & SF & \\
\hline 14 & SF & \\
\hline 15 & St. saprophyticus & 98 \\
\hline 16 & SF & \\
\hline 17 & Enterococcus spp. & $<97$ \\
\hline 18 & St. saprophyticus & 99 \\
\hline 19 & SF & \\
\hline 20 & L. rhamnosus/L. casei & 98 \\
\hline 21 & Acinetobacter spp. & 99 \\
\hline 22 & Acinetobacter spp. & 98 \\
\hline 23 & Acinetobacter spp. & 97 \\
\hline 24 & Acinetobacter spp. & 97 \\
\hline 25 & Staphylococcus spp. & $<97$ \\
\hline 26 & $\begin{array}{l}\text { Leuconostoc mesenteroides subsp. } \\
\text { mesenteroides }\end{array}$ & 100 \\
\hline
\end{tabular}

$S F$ sequencing failure

and DGGE regarding clostridial presence. MPN detected clostridia in cream samples deriving from milk stored without refrigeration or at $18^{\circ} \mathrm{C}$, but no DGGE fragment could be associated to any Clostridium spp.. This observation maybe due to the presence of clostridial spores, which maybe easily detected by MPN, but whose DNA is more difficult to extract than DNA from vegetative cells.

\section{Conclusions}

In general, cow milking is practiced twice a day on farms throughout the world. In uncontrolled thermal regimes, milk may be kept at temperatures close to chilling in cold climates, or at very high temperatures in hot climates. Depending on the environmental conditions, milk must be protected from freezing or, on the contrary, from extensive microbial proliferation at high temperatures. Milk storage time, also plays a defining role on the number and type of microrganisms that may develop. When temperature and storage time of milk are not controlled, microbial concentration of milk is unpredictable. Thus, these two parameters assume a basic importance in the quality of milk.

The conclusions of the present work are: (1) some important information has been added to the microbiological knowledge of the creaming process; (2) milk refrigeration at $18^{\circ} \mathrm{C}$ before creaming controls bacterial development during overnight resting; (3) refrigeration of milk at 12 or $8^{\circ} \mathrm{C}$ for no more than $24 \mathrm{~h}$ do not cause a massive psycrotrophic microflora development, nor physico-chemical and rheological changes; and (4) microbial culture-independent tools may be used not only as complement, but as alternative to the culture-dependent detection, in order to quickly compare a high number of samples (212 in this study).

Acknowledgements This study was financially supported by the project "Qualità dell Filiera Grana-Trentino" of the autonomous province of Trento (Italy). Author Luca Settanni acknowledges Prof. Adriana Bonanno (SENFIMIZO Department, Section of Animal Production, University of Palermo, Palermo, Italy) for critical reading.

\section{References}

Altschul SF, Madden TL, Schäffer AA, Zhang J, Zhang Z, Miller W (1997) Grapped BLAST and PSI-BLAST: a new generation of protein database search programs. Nucleic Acids Res 25:33893402

Belknap RA, Arledge WL, Whaley KW, Wright EO, Zimmerman AF (1978) Sampling dairy and related products. In: Marth EH (ed) Standard methods for the examination of dairy products. American Public Health Association, Washington, pp 33-40

Biggs DA (1978) Instrumental Infrared estimation of fat, protein and lactose in milk: collaborative study. J Assoc Anal Chem 61: $1015-1034$

Corradini C (1995) Chimica e Tecnologia del Latte. Tecniche Nuove, Bologna

Dogan B, Boor KJ (2003) Genetic diversity and spoilage potentials among Pseudomonas spp. isolated from fluid milk products and dairy processing plants. Appl Environ Microb 69:130-138

Ercolini D, Moschetti G, Blaiotta G, Coppola S (2001) Behavior of variable V3 region from 16S rDNA of lactic acid bacteria in denaturing gradient gel electrophoresis. Curr Microbiol 42: 199-202

Formaggioni P, Sandri S, Franceschi P, Malacarne M, Mariani P (2005) Milk acidity, curd firming time, curd firmness and protein and fat losses in the Parmigiano-Reggiano cheesemaking. Ital J Anim Sci 4:239-241

Fossa E, Pecorari M, Sandri S, Tosi F, Mariani P (1994) Il ruolo del contenuto in caseina del latte nella produzione del parmigiano reggiano: composizione chimica, caratteristiche di coagulazione e comportamento tecnologico-caseario del latte. Sci Tec Latt Cas 45:519-535

Foulquié Moreno MR, Sarantinopoulos P, Tsakalidou E, De Vuyst L (2006) The role and application of enterococci in food and health. Int J Food Microbiol 106:1-24 
Fox PF, McSweeney PLH, Cogan TM, Guinee TP (2004) Cheese: chemistry, physics and microbiology. Elsevier, London

Franciosi E, Settanni L, Carlin S, Cavazza A, Poznanski E (2008) A factory-scale application of secondary adjunct cultures selected from lactic acid bacteria during "Puzzone di Moena" cheese ripening. J Dairy Sci 91:2981-2991

Franciosi E, Settanni L, Cavazza A, Poznanski E (2009a) Presence of enterococci in raw cow's milk and "Puzzone di Moena" cheese. J Food Process Pres 33:204-217

Franciosi E, Settanni L, Cavazza A, Poznanski E (2009b) Biodiversity and technological potential of wild lactic acid bacteria from raw cows' milk. Int Dairy J 19:3-11

Gatti M, Lazzi C, Rossetti L, Mucchetti G, Neviani E (2003) Biodiversity in Lactobacillus helveticus strains present in natural whey starter used for Parmigiano Reggiano cheese. J Appl Microbiol 95:463-470

Heeschen WH (1996) Bacteriological quality of raw milk: legal requirements and payment systems. In: Proceedings of IDF bacteriological quality of raw milk symposium, Wolfpassing, Austria. IDF, Brussels, Belgium, pp 1-18

Kohnhorst A (2001) Dairy science and technology. Education series http://wwwfoodsciuoguelphca/dairyedu/homehtml Accessed 15 December 2009

Malacarne M, Summer A, Formaggioni P, Franceschi P, Sandri S, Pecorari M, Vecchia P, Mariani P (2008) Dairy maturation of milk used in the manufacture of Parmigiano-Reggiano cheese: effects on physico-chemical characteristics, rennet coagulation aptitude and rheological properties. J Dairy Sci 75:218-224

Mariani P, Pecorari M, Fossa E (1984) Le caratteristiche di coagulazione del latte delle razze Bruna e Frisona nella produzione del formaggio Parmigiano-Reggiano. Atti Soc It Buiatria 16:319-327

Meiri-Bendek I, Lipkin E, Friedmann A, Leitner G, Saran A, Friedman S, Kashi Y (2002) A PCR-basedmethod for the detection of Streptococcus agalactiae in milk. J Dairy Sci 85: $1717-1723$

Murphy SC, Boor KJ (2000) Trouble-shooting sources and causes of high bacteria counts in raw milk. Dairy Food Environ Sanit 20:606-611

Neviani E, Carini S (1994) Microbiology of Parmesan cheese. Microbiologie-Aliments-Nutritions 12:1-8

Özer BH (2000) Microbiology of liquid milk. In: Robinson RK, Batt CA, Patel PD (eds) Encyclopedia of food microbiology. Academic Press, London, pp 1436-1441

Pecorari M, Sandri S, Mariani P (1987) Attitudine alla coagulazione dei latti delle razze Frisona, Bruna, Reggiana e Modenese. Sci Tec Latt-Cas 38:376-384

Sandri S, Fossa E, Scotti C, Malacarne M (2007) La maturazione del latte durante l'affioramento in diverse condizioni operative: attitudine tecnologica e reologia del coagulo. Sci Tec Latt-Cas $58: 243-255$

Slaghuis B (1996) Sources and significance of contaminants on different levels of raw milk production. In: Proceedings of IDF symposium bacteriological quality of raw milk. Wolfpassing, Austria. IDF, Brussels, Belgium, pp 19-27

Sørhaug T, Stepaniak L (1997) Psychrotrophs and their enzymes in milk and dairy products: quality aspects. Trends Food Sci Tech 8:35-40

Zannoni M, Annibaldi S (1981) Standardization of the renneting ability of milk by Formagraph. Sci Tec Latt-Cas 32:79-94 